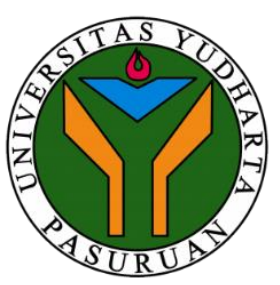

\title{
Implementasi Augmented Reality Pada Aplikasi Android Untuk Memperlihatkan Produk Kaktus
}

\author{
${ }^{1}$ Elok Nur Fauziyah, ${ }^{2}$ Erika Kanya Anggraeni, ${ }^{3}$ Atikah Adawiyyah, ${ }^{4}$ Dodik Arwin Dermawan, ${ }^{5}$ Paramitha Nerisafitra \\ ${ }^{12345}$ Jurusan Teknik Informatika, Fakultas Teknik, Universitas Negeri Surabaya \\ Email :1elok.17051204051@mhs.unesa.ac.id,2erika.17051204053@mhs.unesa.ac.id,3atikah.17051204079@mhs.unesa.ac.id
}

\begin{tabular}{|c|c|}
\hline INFO ARTIKEL & ABSTRAK \\
\hline \multirow[t]{2}{*}{$\begin{array}{l}\text { Katakunci: } \\
\text { Augmented Reality } \\
\text { Aplikasi Android } \\
\text { Produk Kaktus }\end{array}$} & $\begin{array}{l}\text { Augmented Reality (AR) merupakan inovasi dari computer graphic yang dapat menyajikan } \\
\text { visualisasi dan animasi dari sebuah model atau desain objek yang menggabungkan dunia } \\
\text { maya 2D maupun 3D kedalam sebuah dunia nyata. Bentuk pemanfaatan teknologi AR dalam } \\
\text { proses penjualan produk misalnya media penjualan produk kaktus. Penggunaan AR dalam } \\
\text { proses penjualan produk efektif untuk meningkatkan daya tarik pada proses jual beli karena } \\
\text { pembeli seolah-olah dapat melihat langsung prduk yang akan beli meskipun tidak berhadapan } \\
\text { langsung dengan produk yang sesungguhnya. Penelitian ini bertujuan untuk membangun media } \\
\text { penjualan produk kaktus menggunakan media smartphone dan teknologi AR. Sasaran dari } \\
\text { penelitian ini adalah tersedianya metode penjualan produk kaktus yang lebih informatif dan } \\
\text { interaktif. Aplikasi AR diberi nama "Cactus AR" (Cactus Augmented Reality). Objek } 3 \\
\text { dimensi kaktus, suara tentang penjelasan kaktus, dan informasi tentang produk kaktus akan } \\
\text { muncul ketika marker di-scan. "Cactus AR" juga mudah digunakan oleh orang dewasa } \\
\text { maupun anak-anak. }\end{array}$ \\
\hline & ABSTRACT \\
\hline $\begin{array}{l}\text { Keyword: } \\
\text { Augmented Reality } \\
\text { Android Appication } \\
\text { Cactus product }\end{array}$ & $\begin{array}{l}\text { Augmented Reality (AR) is an innovation from computer graphics that can present } \\
\text { visualization and animation of a model or object design that combines } 2 D \text { and } 3 D \text { virtual } \\
\text { worlds into a real world. One of the uses of AR technology is in the process of selling } \\
\text { products for example the media for selling cactus products. The use of AR in the process of } \\
\text { selling products is effective to increase the attractiveness of the buying and selling process } \\
\text { because the buyer will be able to see directly the product they want to buy even though it } \\
\text { is not dealing directly with the actual product. This study aims to build a media for selling } \\
\text { cactus products using smartphone media and AR technology. The objective of this research is } \\
\text { to develop a more informative and interactive method of selling cactus products. The AR } \\
\text { application is named "Cactus AR" (Cactus Augmented Reality). Cactus 3-dimensional objects, } \\
\text { sounds about cactus explanations, and information about cactus products will appear when } \\
\text { the marker is scanned. "Cactus AR" is also easy to use for adults or children. }\end{array}$ \\
\hline
\end{tabular}

@ 2020 diterbitkan oleh Prodi Teknik Informatika Universitas Yudharta Pasuruan

\section{Pendahuluan}

Perkembangan teknologi sangat cepat sehingga menuntut kita untuk memperoleh informasi secara cepat dan mudah, yang saat ini dirasakan semakin menjadi kebutuhan pokok yang mendesak. Kemudahan dalam teknologi untuk mengakses layanan informasi menjadi salah satu pilihan bagi setiap pengguna perangkat komunikasi. Smartphone atau ponsel pintar merupakan salah satu perangkat komunikasi yang menghadirkan kemudahan tersebut, sehingga banyak dijadikan alternatif pilihan pengguna [1], [2]. Penggunaan smartphone berbasis android saat ini meningkat pesat, hal tersebut mengakibatkan para pengembang aplikasi berlomba-lomba menciptakan aplikasi berbasis android [3], [4].

Dengan begitu teknologi sekarang ini secara tidak langsung memberikan dampak kepada masyarakat khususnya dalam perkembangan teknologi multimedia. Augmented Reality (AR) yang merupakan inovasi dari computer graphic sehingga dapat menyajikan visualisasi dan animasi dari sebuah model atau desain objek yang menggabungkan dunia maya 2D maupun 3D kedalam sebuah dunia nyata. AR merupakan sebuah media baru dalam proses belajar mengajar misalnya media pengenalan hewan pada anak-anak [5]-[7].

Pada umumnya aplikasi Augmented Reality memerlukan marker khusus untuk menjalankannya [8], [9]. Karena menggunakan Marker Based Augmented Reality yang hanya dapat dijalankan jika marker yang dibutuhkan tersedia, menjadikan aplikasi terbatas pada penggunaan marker khusus saja sehingga tidak efisien untuk digunakan. Penerapan Markerless Augmented Reality menjadi solusi yang tepat dalam hal ini sebab tidak memerlukan marker khusus untuk mejalankannya [10]-[12]. Markerless Augmented Reality dapat membuat marker sendiri yang akan terbentuk secara otomatis dengan cara memindai sebuah objek yang dipilih dengan menggunakan kamera. Karena penggunaanya yang 
praktis user dapat dengan mudah menggunakan aplikasi [13]. Bentuk marker selain gambar bisa menggunakan opsi lain seperti data matrix codedan QR Code [14].

Dalam penerapannya dibidang jual beli khususnya dalam jual beli produk kaktus misalnya, kita bisa memperlihatkan bagaimana bentuk kaktus yang akan dibeli tanpa perlu datang ke tempat penjualan kaktus. Selain itu dengan adanya aplikasi "Cactus AR" ini kita juga dapat mengetahui informasi lengkap mengenai kaktus. Penggunaanya yang mudah membuat semua kalangan masyarakat nyaman menggunakannya, dan diakses melalui smartphone dengan koneksi internet.

\section{Metodologi Penelitian}

Multimedia Development Life Cycle Menurut Binanto (2010) yang dikutip dari Luther (1994), merupakan metode pengembangan multimedia terdiri dari enam tahap, yaitu Concept, Design, Material Collecting, Assembly, Testing, dan Distribution. Keenam tahap ini tidak harus berurutan dalam praktiknya, tahap-tahap tersebut dapat saling bertukar posisi. Meskipun begitu, tahap Concept memang harus menjadi hal yang pertama dikerjakan [15]. Pada gambar 1 menunjukan alur dari Multimedia Development Life Cycle.

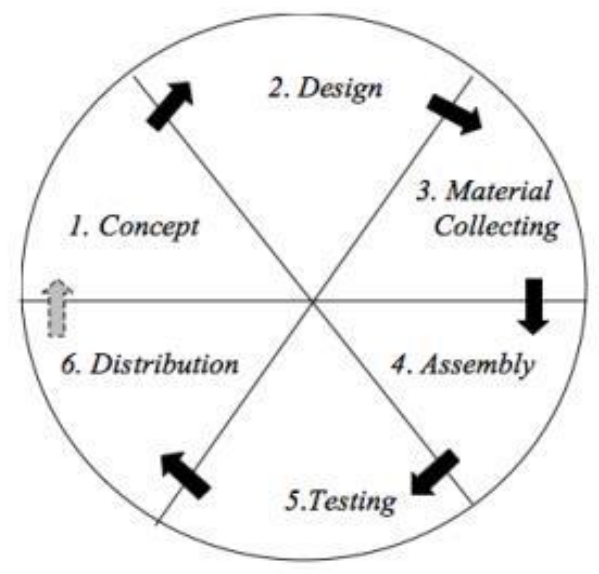

Gambar 1 Alur MDLC

Tahap - tahap tersebut diimplementasikan pada penelitian dengan rincian sebagai berikut:

2.1. Tahap Konsep (Concept)

Penulis melakukan studi literatur tentang animasi 3D dan Augmented Reality. Konsep yang akan dikerjakan sesuai dengan kebutuhan untuk membangun brosur berteknologi Markerless Augmented Reality, yaitu kontenkonten digital dan print-out citra yang telah diolah dengan hasil akhir berupa brosur yang berisi marker. Pembuatan aplikasi media pengenalan kaktus yang informatif dan interaktif dengan adanya suara dan objek 3D yang ditampilkan secara virtual menggunakan teknologi AR untuk membantu pengenalan kaktus. Serta menentukan pengguna aplikasi Cactus AR, pengguna aplikasi tersebut adalah penjual dan pembeli produk kaktus.

2.2. Tahap Perancangan (Design)

Dalam perancangan aplikasi ini dibutuh software Blender 2.82 untuk membuat model kaktus dalam bentuk tiga dimensi dan Unity 3D yang digunakan untuk menerapkan teknologi Augmented Reality-nya, untuk itu diperlukan Storyboard untuk menggambarkan deskripsi tiap marker, dengan mencantumkan semua, berikut adalah tabel Storyboard bentuk objek yang akan dibuat, seperti pada Tabel I. 
Tabel 1 Storyboard

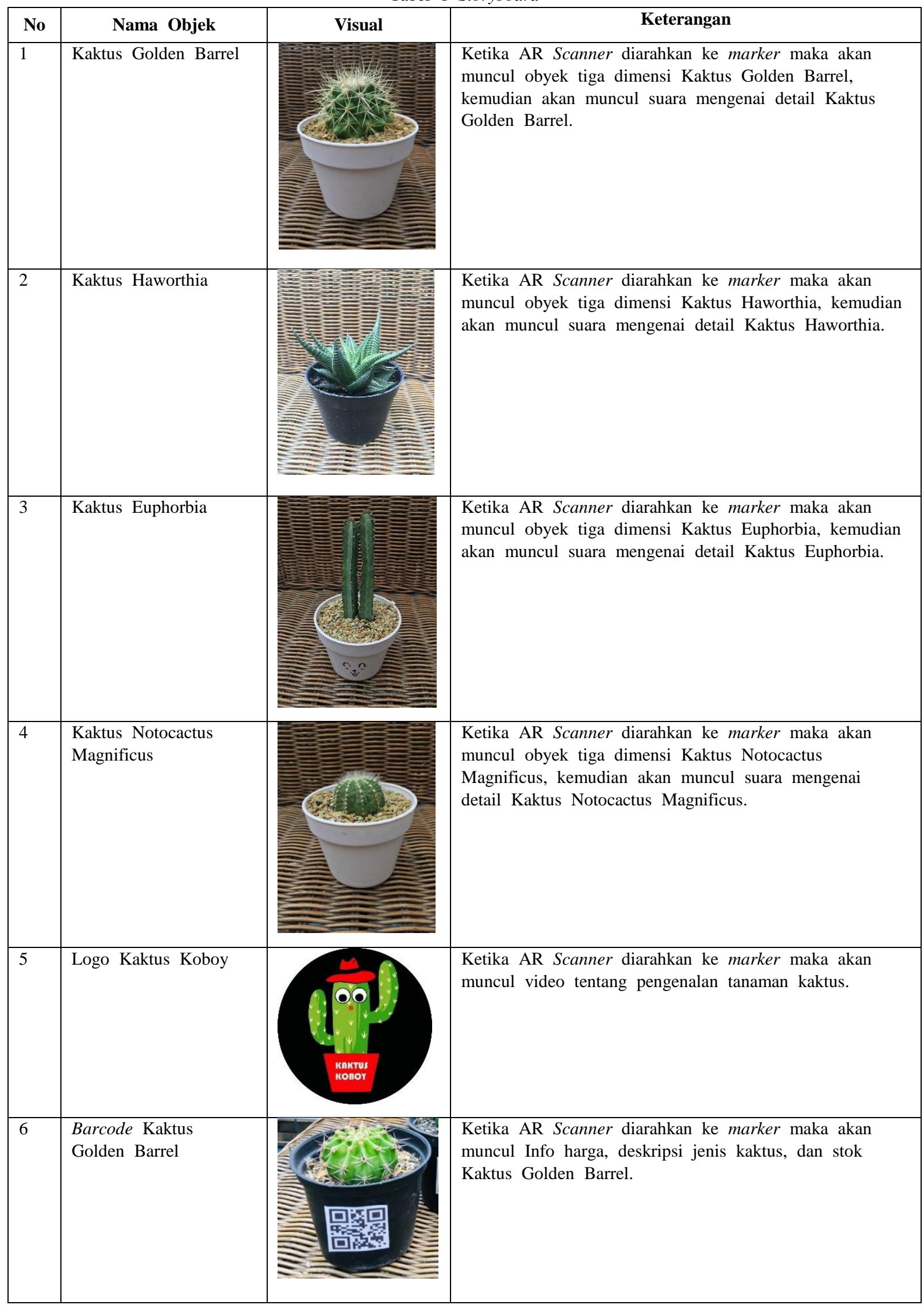




\begin{tabular}{|l|l|l|}
\hline 7 & Barcode Kaktus & Ketika AR Scanner diarahkan ke marker maka akan \\
Haworthia & Kaktus Haworthia. \\
\hline 8 & Barcode Kaktus & \\
Euphorbia & & \\
\hline 9
\end{tabular}

\subsection{Tahap Pengumpulan Bahan (Material Collecting)}

Tahap Material Collection adalah tahap pengumpulan bahan yang berhubungan dengan penelitian. Bahan yang dibutuhkan antara lain teks, gambar sebagai marker atau target, objek 3D, audio, dan animasi yang dapat diperoleh dari berbagai sumber seperti buku, internet, atau gambar yang dibuat sendiri oleh penulis. Gambar yang dijadikan marker terdiri dari 2 jenis yaitu foto dan barcode (tabel II), objek 3D dibuat menggunakan software Blender 2.82 yang nantinya akan menghasilkan 4 objek 3D kaktus, audio yang berisi penjelasan mengenai kaktus dibuat dengan voice recorder pada smartphone, dan video mengenai pengenalan kaktus kami ambil dari Youtube. 
Tabel 2 Penanda/Marker yang dibutuhkan

\begin{tabular}{|c|c|c|c|}
\hline No & Gambar & Ukuran / Format & Keterangan \\
\hline 1 & & $726 \mathrm{~Kb} / J P G$ & $\begin{array}{l}\text { Foto Kaktus Golden Barrel asli yang diambil } \\
\text { langsung oleh penulis dan dilakukan crop dengan } \\
\text { software Adobe Photoshop CS6 dan disimpan } \\
\text { dengan format .jpg. }\end{array}$ \\
\hline 2 & & $766 \mathrm{~Kb} / J P G$ & $\begin{array}{l}\text { Foto Kaktus Haworthia asli yang diambil langsung } \\
\text { oleh penulis dan dilakukan crop dengan software } \\
\text { Adobe Photoshop CS6 dan disimpan dengan format } \\
\text {.jpg. }\end{array}$ \\
\hline 3 & & $772 \mathrm{~Kb} / J P G$ & $\begin{array}{l}\text { Foto Kaktus Euphorbia asli yang diambil langsung } \\
\text { oleh penulis dan dilakukan crop dengan software } \\
\text { Adobe Photoshop CS6 dan disimpan dengan format } \\
\text {.jpg. }\end{array}$ \\
\hline 4 & & $693 \mathrm{~Kb} / J P G$ & $\begin{array}{l}\text { Foto Kaktus Notocactus Magnificus asli yang } \\
\text { diambil langsung oleh penulis dan dilakukan crop } \\
\text { dengan software Adobe Photoshop CS6 dan } \\
\text { disimpan dengan format .jpg. }\end{array}$ \\
\hline 5 & & $74 \mathrm{~Kb} / J P G$ & $\begin{array}{l}\text { Dibuat dengan software Adobe Photoshop CS6 dan } \\
\text { disimpan dengan format .jpg. }\end{array}$ \\
\hline
\end{tabular}




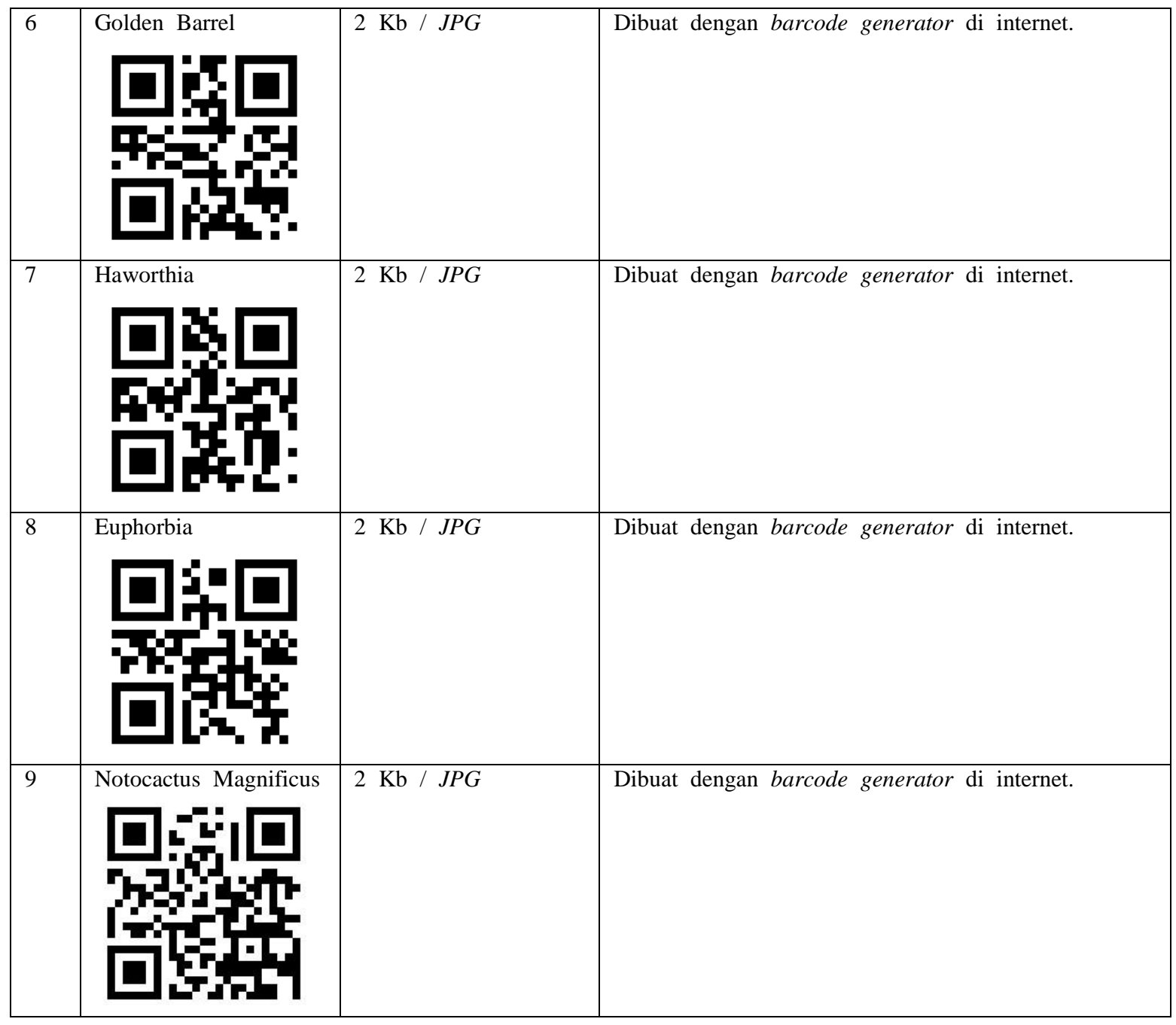

\subsection{Tahap Pembuatan (Assembly)}

Tahap ini adalah tahap proses pembuatan media pembelajaran sesuai dengan storyboard yang telah dibuat pada tahap sebelumnya, aplikasi yang akan dibuat didukung oleh software yaitu Unity 3D, Vuforia, Photoshop, dan Blender. Proses pembuatan (build) aplikasi Android ini dilakukan dalam software Unity. Setelah asset dan scene di gabungkan pada software Unity (gambar 2), kemudian di build sehingga menghasilkan sebuah aplikasi "Cactus AR" menggunakan Augmented Reality berbasis Android dengan format APK. Aplikasi ini dapat digunakan pada smartphone berbasis Android.

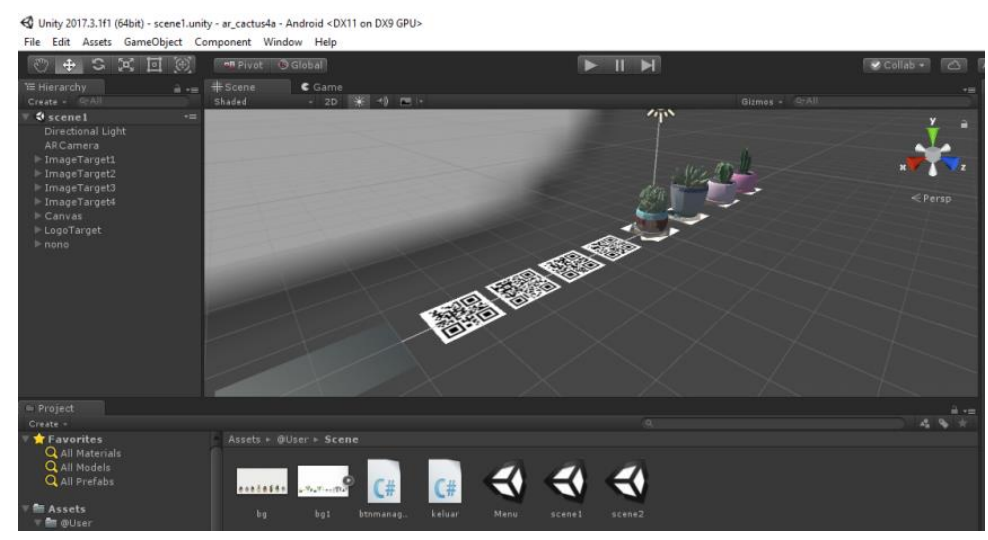

Gambar 2 Proses assembly pada Unity 


\subsection{Tahap Pengujian (Testing)}

Pengujian dilakukan setelah menyelesaikan tahap assembly dengan menjalankan aplikasi AR pada smartphone Android dan dilihat apakah aplikasi dibuat sudah sesuai dengan kebutuhan user dan apakah aplikasi "Cactus AR" ini terdapat kesalahan atau tidak.

2.6. Tahap Distribusi (Distribution)

Pada tahap distribusi penulis mendistribusikan aplikasi yang telah dibuat kepada beberapa user sebagai sampel yang bertujuan untuk melakukan pengukuran apakah tujuan penelitian yang dilakukan sudah tercapai atau tidak.

\section{Hasil Dan Pembahasan}

\section{a. Pembuatan Objek 3D}

Dalam proses pengerjaan/ pembuatan objek 3D ini berlangsung dari modeling sampai dengan rendering dilakukan dengan perangkat lunak Blender 2.82. Objek 3D yang dibuat ada 4 (empat) yaitu objek 3 dimensi Kaktus Golden Barrel, objek 3 dimensi Kaktus Haworthia, objek 3 dimensi Kaktus Euphorbia, dan objek 3 dimensi Kaktus Notocactus Magnificus. Hasil dari pembuatan objek 3D di aplikasi Blender adalah sebagai berikut:

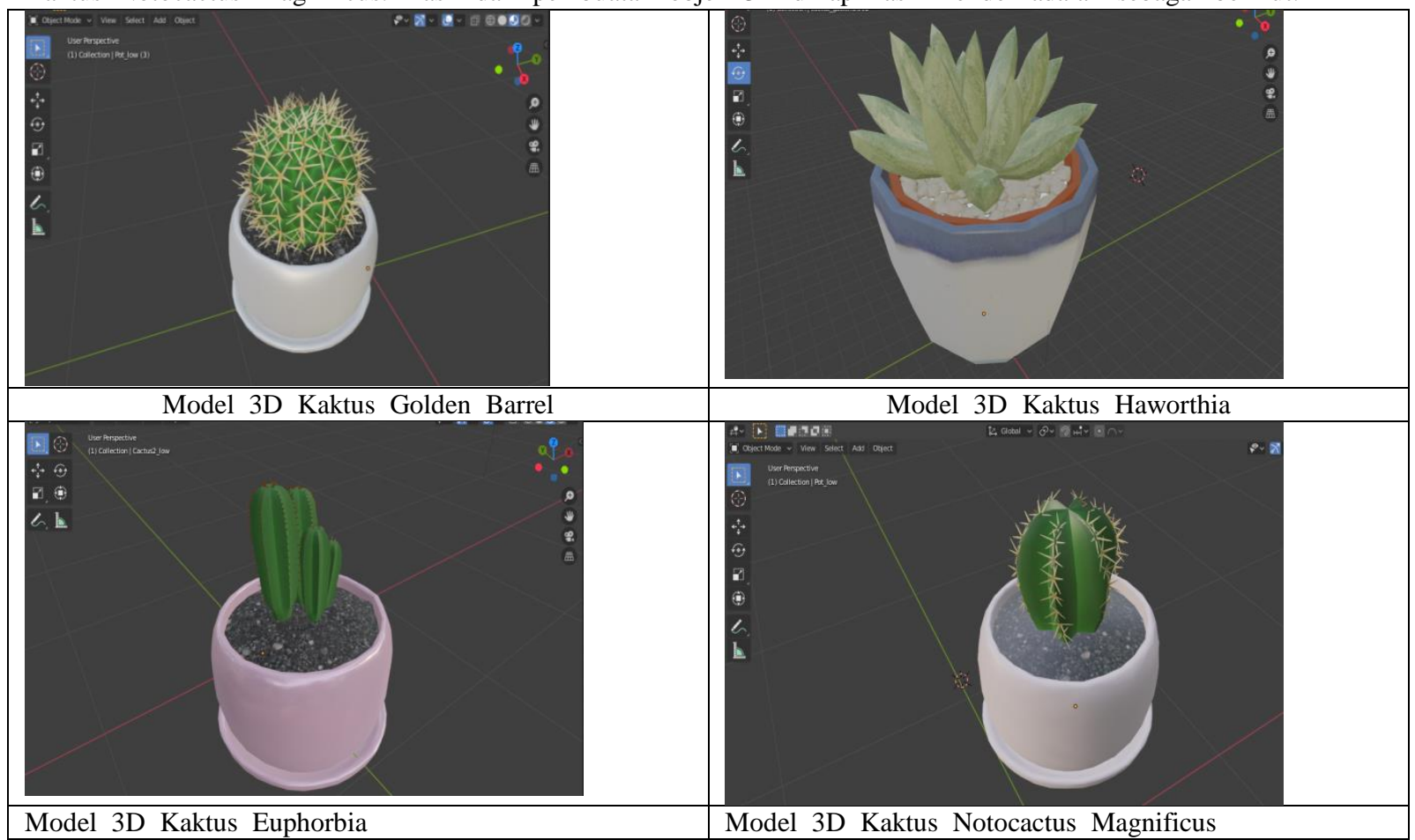

Gambar 3 variasi model 3D kaktus

Setelah dilakukan permodelan 3D dengan menggunakan software Blender, selanjutnya model 3D yang telah dibuat harus dijadikan format $f b x$ agar model 3D bisa dimasukkan ke dalam software Unity 3D sehingga bisa diintegrasikan dengan marker yang kemudian memunculkan Augmented Reality 3D Kaktus.

\section{b. Pembuatan Brosur}

Selanjutnya adalah pembuatan brosur untuk dijadikan Markerless Augmented Reality. Brosur dibuat dengan menggunakan software Coreldraw x8 dan Photoshop CS6. Pada brosur terdapat gambar kaktus dan logo Kaktus Koboy yang dijadikan marker untuk memunculkan Augmented Reality. Hasil pembuatan brosur ditunjukkan pada gambar 7 dan gambar 8 . 


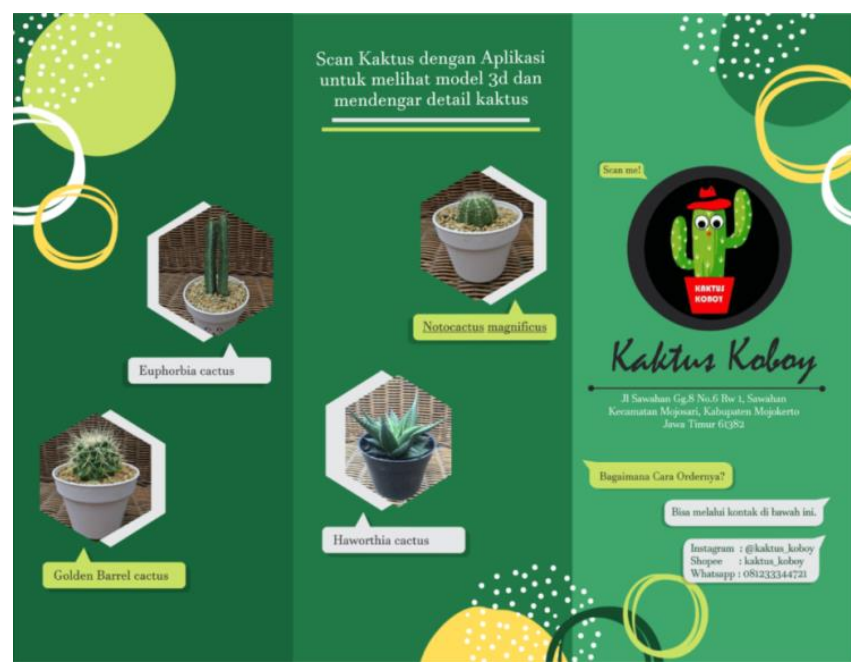

Gambar 4 Halaman Depan Brosur

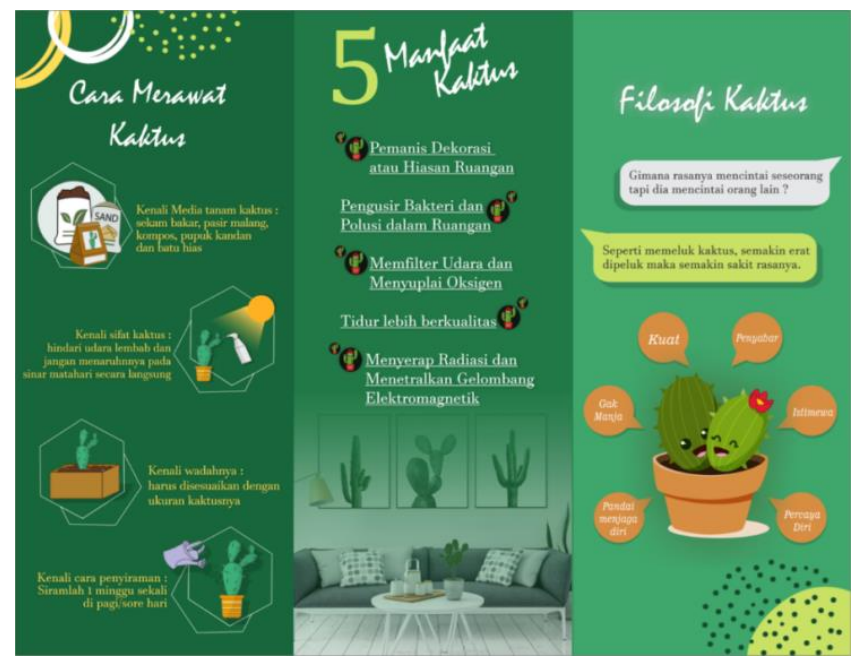

Gambar 5 Halaman Belakang Brosur

Di halaman depan brosur (gambar 7) terdapat gambar kaktus Kaktus Golden Barrel, Kaktus Haworthia, Kaktus Euphorbia, Kaktus Notocactus Magnificus, dan juga Logo Kaktus Koboy yang merupakan marker untuk Augmented Reality. Sedangkan di halaman belakang brosur (gambar 8) terdapat panduan cara merawat kaktus, manfaat kaktus, dan filosofi kaktus sebagai informasi tambahan bagi pembeli produk kaktus.

\section{c. Tampilan dan Pengujian Cactus AR}

Setiap halaman dalam "Cactus AR" akan diuji untuk memastikan apakah aplikasi telah berjalan dengan baik atau tidak. Hasil yang keluar akan dicocokan dengan hasil yang diharapkan. Tahap pengujian dilakukan untuk memastikan apakah aplikasi telah berjalan dengan baik dan dapat digunakan oleh user atau tidak. Tahap ini dilakukan dalam dua tahap. Tahap pengujian yaitu tahap yang dilakukan oleh peneliti. Setelah lolos dari pengujian oleh peneliti, pengujian yang melibatkan user. Berdasarkan pengujian sistem yang telah dilakukan, berikut adalah tampilan dari hasil pengujian:

1. Tampilan Menu

Tampilan menu adalah tampilan awal yang muncul setelah aplikasi "Cactus AR" dijalankan. Pada tampilan menu ada 2 tombol yaitu Start untuk memulai scan pada marker, lalu ada tombol Exit untuk keluar dari program.

\section{BASTOS ARES}

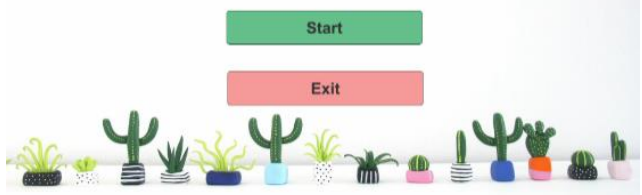

Gambar 6 Halaman awal Cactus AR 


\section{2. $\quad$ Start / Mulai}

Start ini untuk menampilkan objek-objek kaktus 3D dan informasi tentang kaktus dalam bentuk audio sesuai dengan masing-masing objek yang dimiliki oleh tiap marker atau target. Mengarahkan kamera ke marker atau target agar dapat membaca marker dan dapat menampilkan objek-objek kaktus 3D yang sesuai.

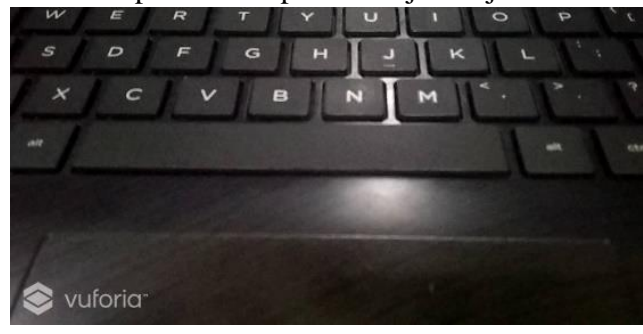

Gambar 7 Tampilan Start

3. Scan Marker Kaktus Golden Barrel

Ketika kamera diarahkan ke marker Kaktus Golden Barrel, hasil yang diharapkan saat gambar marker berhasil ditangkap kamera smartphone cocok, maka objek dan informasi dalam bentuk suara akan tampil.

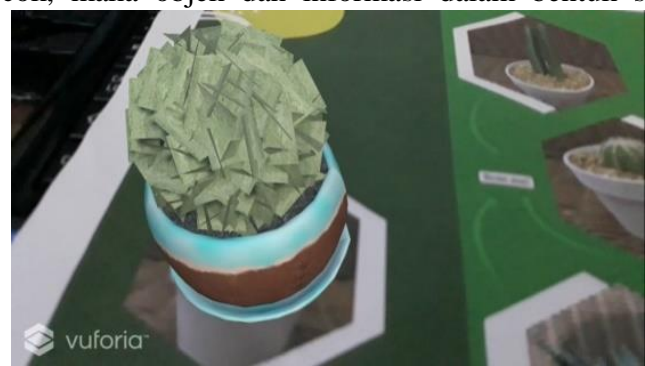

Gambar 8 Objek Kaktus Golden Barrel

4. Scan Marker Kaktus Haworthia

Ketika kamera diarahkan ke marker Kaktus Haworthia, hasil yang diharapkan saat gambar marker berhasil ditangkap kamera smartphone cocok, maka objek dan informasi dalam bentuk suara akan tampil.

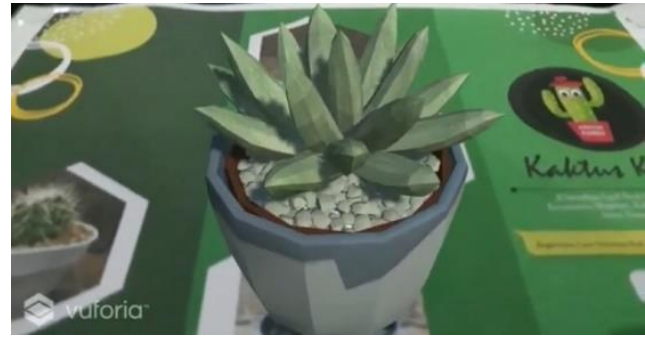

Gambar 9 Objek Kaktus Haworthia

5. Scan Marker Kaktus Euphorbia

Ketika kamera diarahkan ke marker Kaktus Euphorbia, hasil yang diharapkan saat gambar marker berhasil ditangkap kamera smartphone cocok, maka objek dan informasi dalam bentuk suara akan tampil.

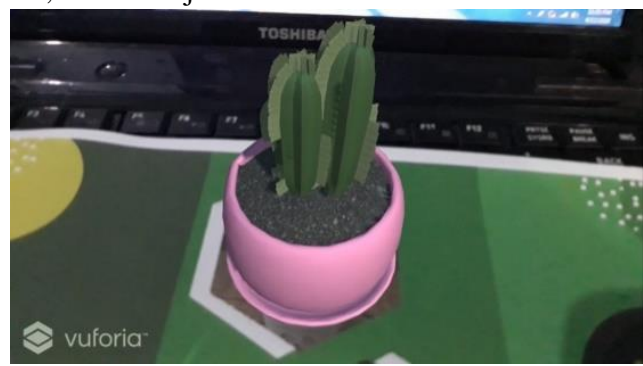

Gambar 10 Objek Kaktus Euphorbia

6. Scan Marker Kaktus Notocactus Magnificus

Ketika kamera diarahkan ke marker Kaktus Notocactus Magnificus, hasil yang diharapkan saat gambar marker berhasil ditangkap kamera smartphone cocok, maka objek dan informasi dalam bentuk suara akan tampil. 
7. Scan Logo Kaktus Koboy

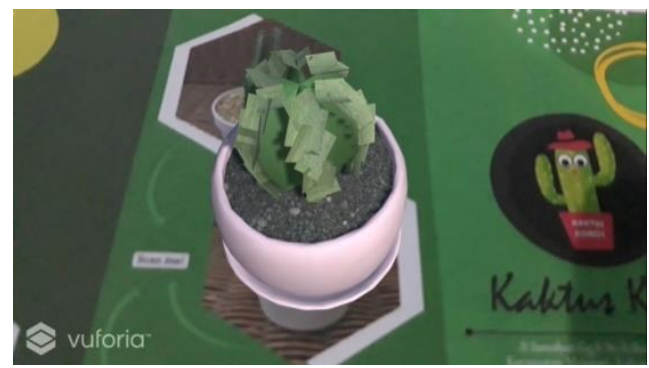

Gambar 11 Objek Kaktus Notocactus Magnificus

Ketika kamera diarahkan ke Logo Kaktus Koboy, hasil yang diharapkan saat gambar marker berhasil ditangkap kamera smartphone cocok, video tentang pengenalan tanaman kaktus maka akan muncul.

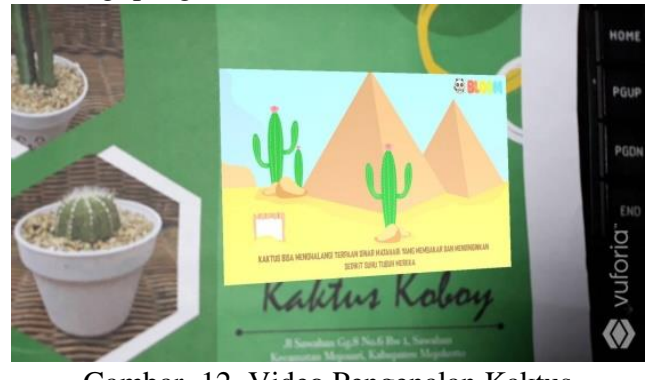

Gambar 12 Video Pengenalan Kaktus

8. Scan Marker Barcode Kaktus Golden Barrel

Ketika kamera diarahkan ke marker barcode Kaktus Golden Barrel, hasil yang diharapkan saat gambar marker berhasil ditangkap kamera smartphone cocok, maka informasi mengenai harga, deskripsi jenis kaktus, dan stok Kaktus Golden Barrel akan tampil.

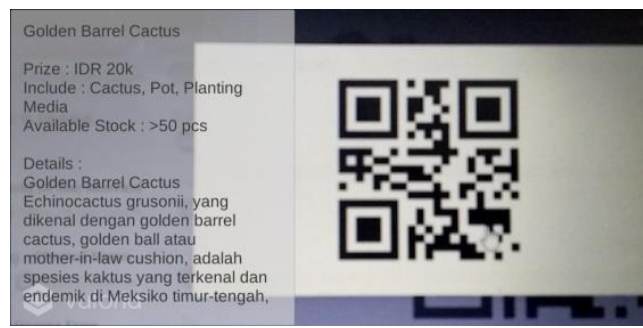

Gambar 13 Informasi Kaktus Golden Barrel

9. Scan Marker Barcode Kaktus Haworthia

Ketika kamera diarahkan ke marker barcode Kaktus Haworthia, hasil yang diharapkan saat gambar marker berhasil ditangkap kamera smartphone cocok, maka informasi mengenai harga, deskripsi jenis kaktus, dan stok Kaktus Haworthia akan tampil.

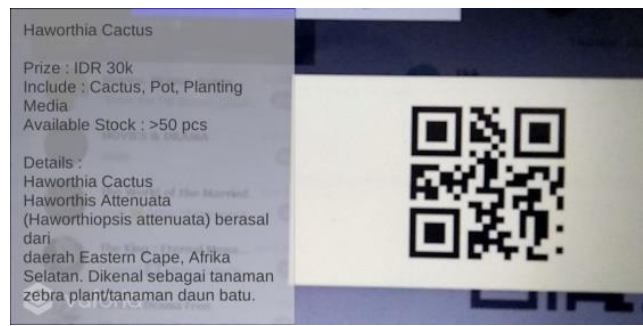

Gambar 14 Informasi Kaktus Haworthia

10. Scan Marker Barcode Kaktus Euphorbia

Ketika kamera diarahkan ke marker barcode Kaktus Euphorbia, hasil yang diharapkan saat gambar marker berhasil ditangkap kamera smartphone cocok, maka informasi mengenai harga, deskripsi jenis kaktus, dan stok Kaktus Euphorbia akan tampil.

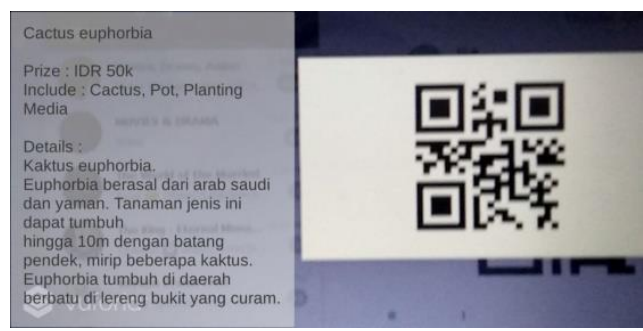

Gambar 15 Informasi Kaktus Euphorbia

11. Scan Marker Barcode Kaktus Notocactus Magnificus 
Ketika kamera diarahkan ke marker barcode Kaktus Notocactus Magnificus, hasil yang diharapkan saat gambar marker berhasil ditangkap kamera smartphone cocok, maka informasi mengenai harga, deskripsi jenis kaktus, dan stok Kaktus Notocactus Magnificus akan tampil.

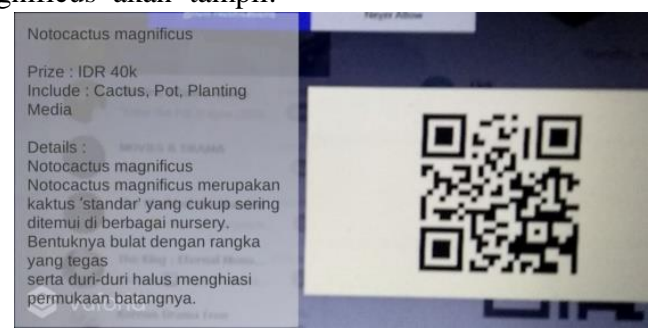

Gambar 16 Informasi Kaktus Notocactus Magnificus

\section{Penutup}

\section{a. Kesimpulan}

Berdasarkan hasil dari pengujian yang telah dilakukan penulis dalam augmented reality pada aplikasi android yang bernama "Cactus AR" untuk memperlihatkan produk kaktus maka dapat ditarik kesimpulan yaitu, informasi yang dipresentasikan dengan augmented reality dalam bentuk objek 3D dan suara pada marker gambar kaktus serta informasi mengenai harga, deskripsi jenis kaktus, dan stok pada marker barcode memudahkan user untuk menerima dan memahami apa yang ingin disampaikan.

b. Saran

Berdasarkan hasil kesimpulan tersebut maka saran oleh penulis adalah sebagai berikut :

1. Mengembangkan scan image pada gambar lebih banyak.

2. Meningkatkan detail model 3D pada software Blender.

3. Membuat aplikasi android/ website untuk system penjualan online.

\section{Referensi}

[1] M. I. Maramis, A. S. M. Lumenta, dan B. A. Sugiarso, "Augmented Reality Pada Aplikasi Android Untuk Memperlihatkan Gedung Fatek," Jurnal Teknik Elektro dan Komputer, vol. 5, no. 1, Art. no. 1, Mar 2016, doi: 10.35793/jtek.5.1.2016.11542.

[2] M. Sarwar dan T. R. Soomro, "Impact of smartphone's on society," European journal of scientific research, vol. 98, no. 2, hlm. 216-226, 2013.

[3] Z. A. Rajput $d k k$., "Evaluation of an Android-based mHealth system for population surveillance in developing countries," $J A m$ Med Inform Assoc, vol. 19, no. 4, hlm. 655-659, Jul 2012, doi: 10.1136/amiajnl-2011-000476.

[4] R. Francese, C. Gravino, M. Risi, G. Scanniello, dan G. Tortora, "Using Project-Based-Learning in a mobile application development course-An experience report," Journal of Visual Languages \& Computing, vol. 31, hlm. 196-205, Des 2015, doi: 10.1016/j.jvlc.2015.10.019.

[5] H. Kaufmann, "Collaborative augmented reality in education," Institute of Software Technology and Interactive Systems, Vienna University of Technology, 2003.

[6] E. Rusnandi, H. Sujadi, dan E. F. N. Fauzyah, "Implementasi Augmented Reality (AR) pada Pengembangan Media Pembelajaran Pemodelan Bangun Ruang 3D untuk Siswa Sekolah Dasar," INFOTECH journal, vol. 1, no. 2, Art. no. 2, Feb 2016, doi: 10.31949/inf.v1i2.40.

[7] S. Wardani, "Pemanfaatan Teknologi Augmented Reality (AR) untuk Pengenalan Aksara Jawa pada Anak," Jurnal Dinamika Informatika, vol. 5, no. 1, Art. no. 1, Nov 2015, Diakses: Nov 01, 2020. [Daring]. Tersedia pada: http://ojs.upy.ac.id/ojs/index.php/dinf/article/view/111.

[8] C. O. Karundeng, D. J. Mamahit, dan B. A. Sugiarso, "Rancang Bangun Aplikasi Pengenalan Satwa Langka di Indonesia Menggunakan Augmented Reality," Jurnal Teknik Informatika, vol. 13, no. 1, 2018.

[9] B. Syihabudin, S. Andryana, dan A. Gunaryati, "The introduction of 3D applications Animal In Indonesia Using Augmented Reality Marker-Based Tracking Method," Informatika, vol. 1, no. 2, hlm. 3, 2020.

[10] Q. H. Gao, T. R. Wan, W. Tang, dan L. Chen, "A stable and accurate marker-less augmented reality registration method," dalam 2017 International Conference on Cyberworlds (CW), 2017, hlm. 41-47.

[11] R. Hammady, M. Ma, dan A. Powell, "User experience of markerless augmented reality applications in cultural heritage museums:'museumeye'as a case study," dalam International Conference on Augmented Reality, Virtual Reality and Computer Graphics, 2018, hlm. 349-369.

[12] M. Jumarlis dan M. Mirfan, "Implementation of Markerless Augmented Reality Technology Based on Android to Introduction Lontara in Marine Society," vol. 156, hlm. 012017, Mei 2018, doi: 10.1088/1755-1315/156/1/012017.

[13] H. Hendratman, The Magic of Blender 3D Modelling. Bandung: Informatic, 2015.

[14] N. Avysa dan M. I. Rosadi, "Aplikasi Pengenalan Dinosaurus Dengan Animasi 3D Berbasis Android Menggunakan Augmented Reality (AR)," JURNAL EXPLORE IT, vol. 11, no. 2, 2019.

[15] Z. C. Rawis, V. Tulenan, dan B. A. Sugiarso, "Penerapan Augmented Reality Berbasis Android Untuk Mengenalkan Pakaian Adat Tountemboan," Jurnal Teknik Informatika, vol. 13, no. 1, 2018, doi: https://doi.org/10.35793/jti.13.1.2018.20190. 